\section{Critical analysis of cystic echinococcosis control programs and praziquantel use in South America, 1974-2010}

\author{
Edmundo Larrieu ${ }^{1}$ and Fabian Zanini ${ }^{2}$
}

Suggested citation: Larrieu E, Zanini F. Critical analysis of cystic echinococcosis control programs and praziquantel use in South America, 1974-2010. Rev Panam Salud Publica. 2012;31(1): $81-7$.

\section{SYNOPSIS}

Cystic echinococcosis (CE) is one of the most prevalent zoonoses in Argentina, Brazil, Chile, Peru, and Uruguay. Control programs in South America were originally modeled after programs developed in insular territories, such as Tasmania and New Zealand. The advent and proven effectiveness of praziquantel, plus the experience of insular models, produced high expectations for rapid advances; however, after 30 years of praziquantel use, no endemic area in South America has obtained eradication.

In fact, only modest gains in CE control have been made and impact on prevalence among humans has been slight. A major impediment has been the infrastructure needed to administer praziquantel to dogs in rural areas 8 times per year over numerous years, a requirement for rapid attack stage 1 . Such an infrastructure has not been financially or politically sustainable in endemic areas, which tend to be the poorest.

On the other hand, certain areas in Argentina have had success with simple and economically viable alternatives. Based primarily on continuous field work supported by the local community, these strategies have significantly decreased transmission to humans, the health sector's main objective. In addition, new possibilities and tools, such as the EG95 vaccine, are being evaluated; as are early detection and treatment of asymptomatic carriers.

Key words: echinococcosis; communicable disease control; praziquantel; epidemiologic surveillance; South America.

1 Facultad de Ciencias Veterinarias, Universidad Nacional de la Pampa, La Pampa, Argentina. Send correspondence to Edmundo Larrieu, email: elarrieu@salud.rionegro.gov.ar

Programa de Control de la Hidatidosis, Subsecretaria de Salud, Tierra del Fuego, Argentina
Cystic echinococcosis (CE) or hydatidosis is a parasitic zoonosis caused by a cestode of the Taeniidae family, Echinococcus granulosus (EG). The parasite requires two mammal hosts to complete its lifecycle; a goat/ sheep, when as a larva it appears as a hydatid cyst in the viscera of ungulates; and a dog/other carnivore, when as an adult it is harbored in the intestines. Several other Echinococcus species exist, for example: $E$. multilocularis, which produces alveolar echinococcosis and is not currently diagnosed in humans in the Region of the Americas; and E. vogeli and E. oligarthrus, which produce polycystic echinococcus (PE) and are present in neotropical areas, with approximately 200 notified cases in a dozen South American countries (1). Regarding EG, several strains have been identified in South America: G1 genotype, the sheep strain, most prevalent in humans, sheep, and cattle; G2, the Tasmanian sheep strain; G3, the cattle strain; G6, the camel strain; and G7, the pig strain $(2,3)$.

$\mathrm{CE}$ is one of the most prevalent zoonotic diseases in Argentina, southern Brazil, Chile, Peru, and Uruguay. In these countries, sheep farming and its associated numbers of working dogs, compounded by the practice of slaughtering adult sheep for home consumption and allowing dogs to feed on infected viscera, generate the ideal conditions for the disease cycle $(4,5)$. It has been estimated (5) that more than 2000 new cases of CE in humans are notified annually by the five countries mentioned. Studies carried out using ultrasound screenings in the asymptomatic human population have permitted more precise measurement of the disease's prevalence in various communities affected. Accordingly, the following infection rates have been reported: 5.5\% in Río Negro, Argentina (1986); 14.2\% in Loncopué, Neuquén, Argentina (1988); 1.6\% in Tacuarembó, Uruguay (1990); $1.6 \%$ in Florida, Uruguay (1997); 3.6\% in Durazno, Uruguay (1998); and $5.1 \%$ in Vichaycocha, Peru (1999) (5-8). These rates indicate that echinococcosis is a very serious health problem in some parts of South America (4).

The cost and social impact of echinococcosis in South America have been measured and were shown to be high $(9,10)$. Livestock losses due to confiscation of viscera are high, but usually are not taken into account since they can be masked by confiscations due to other pathologies, or the losses disappear altogether if confiscations are sold for use in industrial products. Likewise, eventual losses in wool or meat sales have not been accurately measured, and are imperceptible to the farmer who, therefore, does not perceive echinococcosis to be a production issue $(10,11)$.

The objectives of this study are to describe general CE control principles, to analyze the results of the control programs implemented in South America from 
1974-2010, and based on these, to propose future CE strategies.

\section{GENERAL CONTROL PRINCIPLES}

General principles for CE control were developed in 1986 by adapting the four stages of a successful infectious disease control/eradication program specifically to CE (12):

(i) Preparation-establish program structure, surveillance system, staff training

(ii) Attack-implement control measures that destabilize parasite

(iii) Consolidation-identify/eliminate remaining focal points using intensive surveillance

(iv) Eradication (maintain measures that avoid reintroduction)

Early control programs in South America had been based on the experiences of programs on the islands of Tasmania and New Zealand, deworming dogs, first with arecoline bromhidrate, and later, with praziquantel $(13,14)$. Following the 1977 introduction of praziquantel-a tenicide, not an ovicide, with $100 \%$ efficacy against all forms of E. granulosus (15)—new programs were planned in Argentina, Brazil, Chile, Peru, and Uruguay $(5,14)$. Expectations were high for rapid advances in CE control; finally, a safe and efficient drug could be coupled with the experience of the insular models.

The new CE control plan in these five countries used praziquantel at a dose of $5 \mathrm{mg} / \mathrm{kg}$ on all dogs in rural areas. In endemic areas where ecological, epidemiologic, and socioeconomic conditions greatly favored the reinfection of dogs, the plan was to administer the treatment every 45 days, i.e., within the parasite's prepatent period, a total of 8 times/year. Hence, in spite of constant reinfections, parasites would not reach the gravid stage within the dogs' intestines, and therefore, eggs would not be released in the feces (16). If these actions could be sustained for 9-10 years-the estimated period required to replace all infected sheep with new animals and for the inactivation of preexistent eggs in the environment-the parasite would be destabilized, and the risk to humans, eliminated $(12,16)$.

This praziquantel-based deworming plan presented important challenges. Extensive field infrastructure, in terms of both personnel and vehicles, was required to deworm either a very large dog population, such as that of Uruguay, or a smaller, but more widelydistributed one, such as those of southern Argentina and the central sierra of Peru. Moreover, roads in these larger areas were often inaccessible. Finally, this considerable infrastructure would need to be funded and maintained throughout the 9-10 year period.

In recent years, new technology has been developed for controlling $\mathrm{CE}$, that if combined with an adequate use of praziquantel, can reduce the control time (17). The EG95 vaccine, which has been shown to pro- tect sheep against first and repeated E. granulosus infection in experimental models, has achieved $82 \%$ protection with one dose, $97 \%$ with two, and $100 \%$ with three (18). Nevertheless, this vaccine was not available for use until 2010. Currently programs incorporating its use are being carried out in Argentina (Chubut and Río Negro provinces) with vaccines donated by Melbourne University (Melbourne, Australia).

Another strategy added by some programs was the early diagnosis of asymptomatic populations using serologic or ultrasound screening associated with albendazole treatments. Although this activity is not directly linked to interrupting the transmission cycle, it permits important reductions in morbidity and mortality rates and length of hospital stay $(19,20)$.

\section{Drug and vaccine management}

Praziquantel use presents several logistical challenges: a taste and smell that dogs find displeasing; no assurance that each dog has ingested the full dose; difficulty determining correct dose, since weight is estimated in the field (usually results in under-treatment); reluctance of dog owners to administer the numerous pills required at each deworming; reliance on dog owner rather than field worker for administration; and more. This situation has not been previously described, but has been observed by the authors in field.

Regarding sheep vaccination, there are challenges that should be resolved prior to implementing new control programs: resistance from sheep farmers who do not acknowledge an echinococcosis problem in their flock and are not accustomed to vaccinating sheep; the long parturition period in endemic areas, i.e., vaccinating animals at the tail end of parturition, while those at the head eat contaminated pastures; and limited resources available to small farmers for administering vaccinations.

\section{CONTROL PROGRAM RESULTS}

Several authors $(4,5,13,14)$ have published extensive reviews of CE control programs in South America. A summary of each control program's structure, praziquantel use, and current results appears in Table 1. Figure 1 shows the current status of the programs. A detailed evaluation of each control program follows:

\section{Argentina}

Argentina's CE control programs are carried out independently by the various provinces:

Neuquén. The CE control program in Province of Neuquén was launched in 1970 and was structured vertically within the health sector. Initially, the work was carried out in the small department of Huiliches (7 561 $\mathrm{km}^{2}$ ) applying arecoline bromhidrate every 45 days with the program's dosing equipment, personnel, and vehicles. The effort was later extended to the whole 
TABLE 1. Impact of cystic echinococcosis control programs in South America, 1974-2010

\begin{tabular}{|c|c|c|c|c|c|}
\hline \multirow[b]{2}{*}{ Area } & \multicolumn{5}{|c|}{ Prevalence } \\
\hline & Initial & \multicolumn{2}{|c|}{ Final } & \multicolumn{2}{|c|}{ Current } \\
\hline \multicolumn{6}{|l|}{ Argentina } \\
\hline Year & 1995 & \multicolumn{2}{|c|}{2004} & \multicolumn{2}{|c|}{2010} \\
\hline $\begin{array}{r}\text { Year } \\
\text { Children } 0-14 \text { years of age (per } 100000 \text { ) }\end{array}$ & 22.1 & \multicolumn{2}{|c|}{$6.2-28.0$} & \multicolumn{2}{|c|}{-} \\
\hline Sheep (\%) & - & & & & \\
\hline \multicolumn{6}{|l|}{ Río Negro } \\
\hline Year & 1980 & \multicolumn{2}{|c|}{1998} & \multicolumn{2}{|c|}{ 2008-2010 } \\
\hline Children (\%) & 5.6 & \multicolumn{2}{|c|}{1.8} & \multicolumn{2}{|c|}{0.3} \\
\hline Dogs $(\%)$ & 41.2 & \multicolumn{2}{|c|}{18.0} & \multicolumn{2}{|c|}{5.2} \\
\hline Sheep (\%) & 61.0 & \multicolumn{2}{|c|}{2.9} & \multicolumn{2}{|c|}{20.0} \\
\hline \multicolumn{6}{|l|}{ Tierra del Fuego } \\
\hline Year & 1980 & \multicolumn{2}{|c|}{2001} & \multicolumn{2}{|c|}{ 2008-2010 } \\
\hline Children (\%) & & \multicolumn{2}{|c|}{0.2} & & \\
\hline Dogs (\%) & 41.1 & & & & \\
\hline Sheep (\%) & 52.0 & & & & $\mathrm{mb})$ \\
\hline Brazil & & & & & \\
\hline Livramento & & & & & \\
\hline Year & 1983 & & & & \\
\hline Children (\%) & 1.7 & & & & \\
\hline Dogs (\%) & 28.3 & & & & \\
\hline Sheep (\%) & - & & & & \\
\hline Chile & & & & & \\
\hline Region XI & & & & & \\
\hline Year & 1982 & 1991 & 1997 & 2002 & 2010 \\
\hline Human (per 100 000) & 38.0 & 11.8 & 6.0 & - & - \\
\hline Dogs (\%) & 31.0 & 1.6 & 6.5 & 48.2 & - \\
\hline Sheep (\%) & 60.0 & 5.0 & - & & \\
\hline Region XII & & & & & \\
\hline Year & 1979 & 1991 & 1997 & & \\
\hline Human (per 100 000) & 80.0 & 20.0 & - & & \\
\hline Dogs (\%) & 71.0 & 5.0 & 0.3 & & \\
\hline Sheep (\%) & 80.0 & 25.0 & - & & \\
\hline Peru & & & & & \\
\hline Central highlands & & & & & \\
\hline Year & 1974 & 1978 & 2002 & & \\
\hline Children (\%) & - & 5.1 & - & & \\
\hline Dogs (\%) & 11.4 & - & 1.6 & & \\
\hline Sheep (\%) & 52.0 & - & - & & \\
\hline Uruguay & & & & & \\
\hline Year & 1991 & 199 & 998 & & \\
\hline Humans (per 100 000) & 12.4 & & & & \\
\hline Dogs (\%) & 10.1 & & & & \\
\hline Sheep (\%) & 41.0 & & & & \\
\hline
\end{tabular}

Source: Adapted from Craig PS, Larrieu E. Control of cystic echinococcosis-hydatidosis: 1863-2002. Adv Parasitol. 2006;61: 443-508.

province, and included praziquantel use (13). Later, political changes in the health sector led to modified control strategies, including decentralized field activities and transfer of some deworming activities to the municipalities.

A review of the human echinococcosis situation in Neuquén shows that the incidence rate in the 0-14 year age group went from 22.1 per 100000 in 1995 to $6.2 \times 100000$ in 2004, although some areas still have rates of approximately 28 per 100000 children. The Neuquén program successfully decreased the transmission rate to humans; nevertheless, after 34 years, focal areas with high transmission rates still remain (21).

Tierra del Fuego. The CE control program in the Province of Tierra del Fuego was launched in 1976 with a simple structure dependent upon the health department. It consisted of just one veterinarian responsible for oral administration of liquid praziquantel to $100 \%$ of the dogs distributed among approximately 75 large livestock establishments. Deworming was carried out only once every 6 months ( 2 doses/year) due to challenges resulting from the weather and the lack of resources and infrastructure (22). A top priority of the program in Tierra del Fuego was construction of enclosed slaughterhouses and kennels to decrease reinfection among the dogs.

In 1997-2006, ultrasound surveys of children 4-17 years of age showed prevalences of $0.0 \%$ and $0.9 \%$ among this population group $(22,23)$. Thus, the program in Tierra del Fuego was able to cut off transmission to humans almost completely in about 30 years. 
FIGURE 1. Current status of cystic echinococcosis control program in South America, 2010

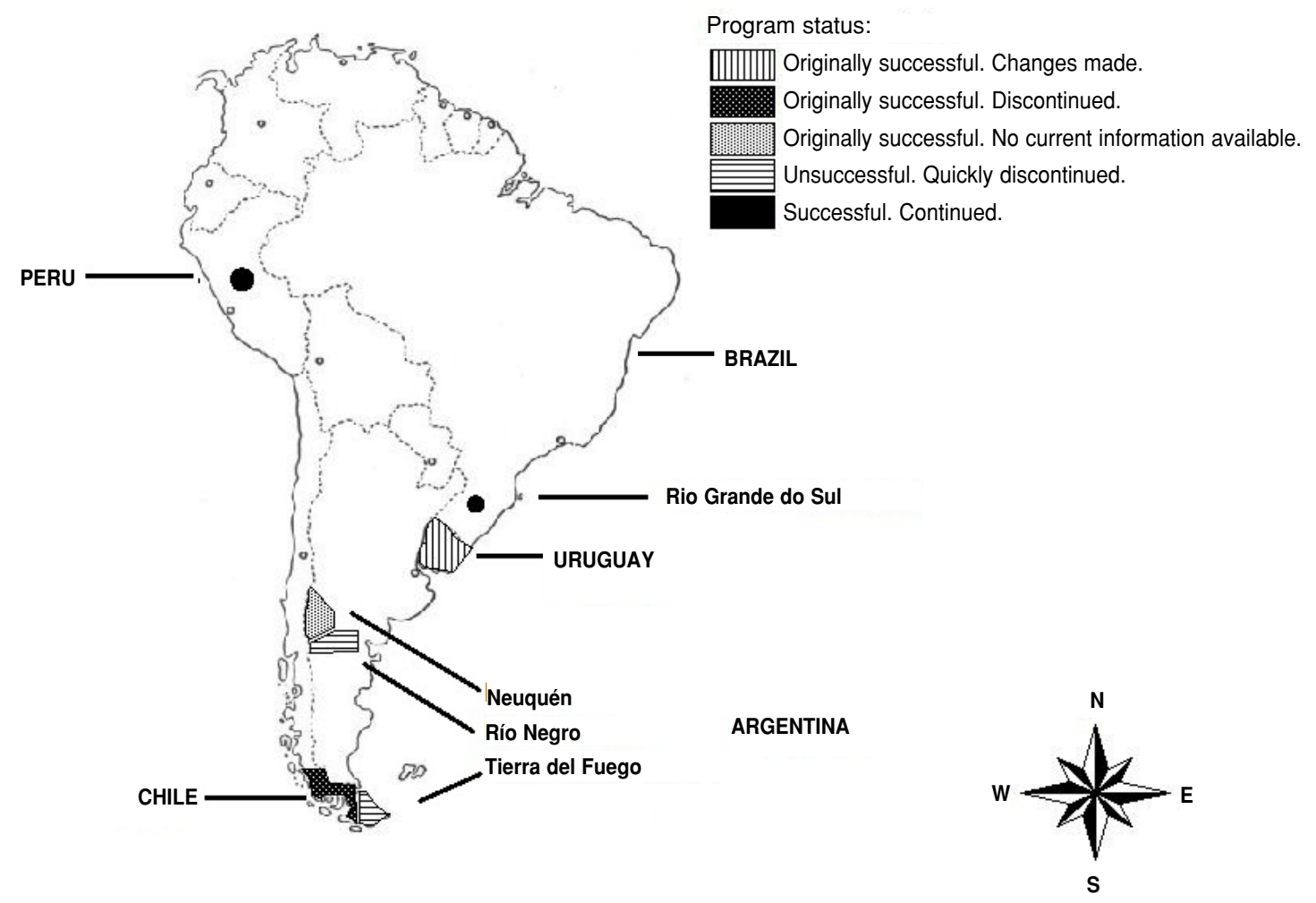

Río Negro. The CE control program in the Province of Río Negro was launched in 1980 using the existing primary health care infrastructure to deworm dogs. A group of health care assistants (nonprofessional staff) conducted home visits, while veterinarians from the health department lent support and managed the surveillance system. This network carried out four rounds of home visits annually. The health care assistants visited rural areas distributing praziquantel tablets to dog owners who were ultimately responsible for carrying out the deworming. For part of the year, geography and climate limited the number of visits and deworming coverage. Nevertheless, the program operated continuously from the start (24).

In 1986, ultrasound surveys of children 6-14 years of age showed CE prevalence at $5.6 \%$; by 2008 , it was down to $0.3 \%$ (25). So, although echinococcosis in Río Negro remains endemic among dogs and sheep, transmission to humans has been significantly decreased.

\section{Uruguay}

The CE control program in Uruguay was launched in 1992 and structured much like that of New Zealand (12). It was a special commissionCommission for Combating Hydatidosis-with administrative ties to the health sector; however, the national program has evolved over the years. At inception in 1992, the infection rate in sheep was stable at approximately $40 \%$. The national program was then restructured, so that deworming of dogs was carried out every 30 days by nonprofessionals assigned exclusively to the program. The restructured program increased coverage, involved numerous veterinarians and all-terrain vehicles, and was funded by canine registration fees. By 1995, deworming was being carried out in over $90 \%$ of the country; by 1997 , the prevalence rate among dogs was drastically reduced to $0.7 \%$, and consequently, national incidence among humans dropped to 6.5/100 000 individuals $(14,26)$. At this point, the Uruguayan model had been particularly successful and was on track to eradicate E. granulosus in Uruguay in 5 years.

In 2006-2007, political changes gave rise to structural changes that expanded the Commission for Combating Hydatidosis and renamed it the Zoonosis Control Commission; new surveillance systems were introduced; and new initiatives were adopted, such as castration for dog population control. To date the results of these changes on CE prevalence have not been published.

Brazil

The need for a national CE control program has been recognized since 1941 (11); nevertheless, only 
sporadic actions have been undertaken, and have been thwarted by lack of a structured and coordinated control program.

Río Grande do Sul. A pilot program in Santana do Livramento was the most effective effort to date. It included a thorough evaluation of the situation (for example, infection rate of $28 \%$ among canines) and a deworming plan using praziquantel. The infection rate dropped to $0 \%$, but was maintained for only 8 months, and rapidly increased from there $(11,27)$. Thus, in Brazil E. granulosus maintains its endemic levels.

Peru

In 1974, the health department launched an CE control program in the central sierras of Peru, an area where indigenous farmers are members of a peasant social organization called Sociedad Agraria de Interés Social (SAIS) and where the Tupac Amaru and Pachacutec peoples live. The control effort utilized arecoline bromhidrate administered to dogs by SAIS veterinary services. In 1974-1978, the infection rate in dogs decreased (28), but the territory fell hostage to guerrilla warfare and the effort had to be discontinued. No other attempts at CE control have been carried out. Recent studies show high prevalence rates in sheep and humans $(4,29)$.

\section{Chile}

The only CE control program that Chile has implemented was launched in 1982 and was structured as a vertical program carried out by the Servicio Agrícola Ganadero (Livestock Agricultural Service, SAG). This was a national program, but was only implemented in two of Chile's "regions" (organized by regions, Chile does not have provinces).

Regions XI and XII. Official SAG veterinarians were responsible for deworming dogs with praziquantel 8 times per year for 15 years, with a brief period of cost constraints during which deworming was lowered to 2 times per year. Praziquantel was delivered to each farm (in Region XII) or to gatherings/concentrations of dog owners (in Region XI), with over $90 \%$ coverage being achieved. The pill distribution strategy was determined by the ecological conditions of the area and the accessibility and size of the farm $(13,30)$.

By 1997, CE incidence rates in humans had dropped to 6 per 100000 in Region XI and 20 per 100000 in Region XII, making the Region XII model one of the most successful ones in South America and leading E. granulosus to a probable state of extinction $(13,30)$. Nevertheless, in 1998 the vertical program was dismantled and decentralized to Chile's various regions, losing coverage. Currently, deworming is voluntary and carried out by farmers. A recent study (31) using coproantigens to measure prevalence in dogs showed the rate to be $48.2 \%$.

\section{STRATEGIES FOR THE FUTURE}

Information on CE in South America confirms that the parasite is widely distributed and reaches high endemic levels $(4,13)$. The large number of cases notified and the results of cross-sectional studies using ultrasound show $\mathrm{CE}$ to be one of the more prevalent zoonosis in South America $(6,13)$. For this reason, the health authorities have promoted CE control programs. However, 30 years after the introduction of a $100 \%$ efficient and safe drug-praziquantel-no endemic area in South America has reached the eradication stage and only two (Chile's Region XII and Uruguay's national program, phase two) have sustained attack stages consistent with Gemmel's predictions (16). Of the two near-successes, one was discontinued, and the other, modified.

Partial or total discontinuation of control programs has been a recurring issue, one that dissolves the important advances made in just a few years, i.e., the case in Chile (31). In other cases, program duration has been adequate, but the coverage is lacking, so the effort must be sustained indefinitely, i.e., the case of Argentina (21, 25).

In most endemic areas, it has not been possible to organize any consistent control programs; such is the case in Brazil and Peru, and in many endemic parts of Argentina and Chile. Areas favored with successful control programs, ones that have decreased CE prevalence and have maintained their improved status, are few. Praziquantel use has permitted some strong local results, but modest overall results, the main challenges being effective administration of the drug to the dogs and the deficient infrastructure, which jeopardizes delivery of the drug (a minimum of 8 times per year for several years). The long-term continuity required to carry out the rapid attack stage as defined previously (16) has not been viable due to economic and/or political inconsistencies in endemic areas, typically the poorest. Given the situation, eradication is not possible.

The experience in some provinces in Argentina with simple, low-cost, and viable alternatives has been successful in obtaining important decreases in transmission to humans. These efforts, which mainly involve continuous field work funded by the surrounding community, may not have attained the planned deworming coverage or an important effect on sheep, but have obtained the main objective of the health sector: decreased transmission to humans $(5,14,23,25)$. As a result, these experiences seem to indicate that, in endemic areas, the number of human cases could be reduced with less infrastructure and cost than that required by a rapid attack stage. The steps of this alternative approach are as follows:

- Identify populations at risk, on whom the existing resources should be used

- Identify farms with persistent levels of transmission

- Determine the speed of reinfection in dogs, so that the frequency of deworming can be adjusted to local epidemiological needs (32) 
- Structure programs to consider geographic distribution so coverage can be sustained over time

- Take advantage of the primary health care structure for deworming and health education campaigns

- Use EG95 vaccine in sheep, but only if funds and infrastructure are consistently available to annually vaccinate all of the sheep in the coverage area

- Have sheep farmers actively participate in the control and vaccination program

- Employ active strategies and ultrasound screenings to detect asymptomatic carriers (before the cyst has produced any damage), especially among children; treat with albendazol and follow-up new cases

These strategies are also complementary to control efforts where EC cannot be eradicated $(6,19,20)$. However, efforts to reduce prevalence and/or eradicate the disease must be continued and maintained by health authorities.

\section{SINOPSIS}

\section{Análisis crítico de los programas de control de la equinococosis quística y uso del prazicuantel en América del Sur, 1974-2010}

La equinococosis quística (EQ) es una de las zoonosis más prevalentes en Argentina, Brasil, Chile, Perú y Uruguay.
Los programas de control en América del Sur fueron originalmente hechos a imitación de los programas desarrollados en territorios insulares, como Tasmania y Nueva Zelandia. El advenimiento y la eficacia comprobada del prazicuantel, sumados a la experiencia de los modelos insulares, dieron lugar a altas expectativas de adelantos rápidos; sin embargo, después de 30 años de uso del prazicuantel, ninguna zona endémica en América del Sur ha logrado la erradicación de la enfermedad.

De hecho, solo se han obtenido avances moderados en el control de la EQ, y su repercusión sobre la prevalencia en seres humanos ha sido leve. Un impedimento mayor ha sido la infraestructura necesaria para administrar el prazicuantel a los perros en zonas rurales 8 veces por año durante varios años, un requisito para el estadio 1 de ataque rápido. Tal infraestructura no ha sido sostenible desde el punto de vista económico o político en las zonas endémicas, que tienden a ser las más pobres.

Por otro lado, ciertas áreas de la Argentina han tenido éxito con opciones sencillas y económicamente viables. Basadas principalmente en el trabajo continuo en el terreno apoyado por la comunidad local, estas estrategias han reducido significativamente la transmisión a los seres humanos, que es el objetivo principal del sector de la salud. Además, se están evaluando nuevas posibilidades y herramientas, como la vacuna EG95, al igual que la detección temprana y el tratamiento de los portadores asintomáticos.

Palabras clave: equinococosis; control de enfermedades transmisibles; praziquantel; vigilancia epidemiológica; América del Sur.

\section{REFERENCES}

1. D'Alessandro A, Rausch RL. New aspects of neotropical polycystic (Echinococcus vogeli) and unicystic (Echinococcus oligarthrus) echinococcosis. Clin Microbiol. 2008;21:380-401.

2. Moro PL, Nakao M, Ito A, Schantz PM Cavero C, Cabrera L. Molecular identification of Echinococcus isolates from Peru. Parasitol Int. 2008;8:184-6.

3. De la Rue ML, Takano K, Brochado JF, Costa CV, Soares AG, Yamano K, et al. Infection of humans and animals with Echinococcus granulosus (G1 and G3 strains) and E. ortleppi in Southern Brazil. Vet Parasitol. 2011;177:97-103.

4. Moro P, Schantz PM. Cystic echinococcosis in the Americas. Parasitology Int. 2006;55:5181-6.

5. Larrieu E, Belotto A, Arambulo P, Tamayo H. Cystic echinococcosis: epidemiology and control in South America. Parasitol Latinoamer. 2004;59:82-9.

6. Frider B, Larrieu E. Treatment of liver hydatidosis: how to treat an asymptomatic carrier? World J Gastroenterol. 2010; 16:4123-9.

7. Carmona C, Perdomo R, Carbo A, Alvarez C, Monti J, Graubert D, et al. Risk factors associated with human cyst Echinoccoc- cosis in Florida, Uruguay: results of a mass screening study using ultrasound and serology. Am J Trop Med Hyg. 1998;58.

8. Frider B, Losada C, Larrieu E, De Zavaleta O. Asymptomatic abdominal hydatidosis detected by ultrasonography. Acta Radiol. 1998;29:431-4.

9. Larrieu E, Mercapide G, Del Carpio M, Salvitti JL, Costa MT, Romeo S, et al. Evaluation of the losses produced by hydatidosis and cost/benefit analysis of different interventions of control in the Province of Rio Negro, Argentina. Bol Chilen Parasitol. 2000;55:8-13.

10. United Nations Food and Agriculture Organization. Estimación del impacto economico de la Equinococcosis Quistica en el Cono Sur (Argentina, Brasil, Chile y Uruguay). Montevideo (Uruguay): FAO; 2007.

11. De La Rue M. Cystic echinococcosis in southern Brazil. Rev Inst Med Trop S Paulo. 2008;50:53-6.

12. Gemmel MA, Lawson JR. Epidemiology and control of hydatid disease. In: Thompson R, Lymbery J.The biology of Echinococcus granulosus and hydatid disease. London: George Allen and Unwin; 1986. Pp. 186-216.
13. Craig PS, Larrieu E. Control of Cystic Echinococcosis-Hydatidosis: 1863-2002. Adv Parasitol. 2006;61:443-508.

14. Economides P, Larrieu E, Orlando D. Evolution of programmes for control of Echinococcus grabulosus. In: Eckert J, Gemmel MA, Meslin FX, Pawlowski Z. Manual on Echinococcosis in humans and animals: a public health problem of global concern. France: WHO/OIE; 2001. Pp. 204-9.

15. Thakur AS, Prezioso U, Marchevsky N. Efficacy of droncit against Echinococcus granulosus infection in dogs. Am J Vet Res. 1977;39:859-60.

16. Gemmel MA, Roberts MG, Beard TC, Campano Diaz S, Lawson JR, Nonnemaker JM. Control of Echinococcosis. In: Eckert J, Gemmel MA, Meslin FX, Pawlowski ZT. Manual on Echinococcosis in humans and animals: a public health problem of global concern. France: WHO/OIE; 2001. Pp 195-203.

17. Torgerson PR. Mathematical models for the control of cystic echinococcosis. Parasitol Int. 2006;55(Suppl):S253-8.

18. Heath DD, Jensen O, Lightowlers MW. Progress in control of hydatidosis using vaccination-a review of formulation 
and delivery of the vaccine and recommendations for practical use in control programmes. Acta Trópica. 2003;85: $133-43$.

19. Larrieu E, Del Carpio M, Mercapide $\mathrm{CH}$, Salvitti JC, Sustercic J, Moguilensky J, et al. Programme for ultrasound diagnoses and treatment with albendazole of cystic echinococcosis in asymptomatic carriers: 10 years of follow-up of cases. Acta Tropica. 2010;117:1-5.

20. Del Carpio M, Mercapide $\mathrm{CH}$, Salvitti JC, Uchiumi L, Sustercic J, Panomarenko J, et al. Early diagnosis, treatment, and follow-up of cystic echinococcosis in remote rural areas in Patagonia: impact of ultrasound training of non-specialists with a focused approach on CE. Plos Neg Tro Dis. 2011; in press.

21. Pierangeli NB, Soriano SV, Rocía I, Jiménez J, Lazzarini LE, Grenóvero MS, et al. Heterogeneus distribution of human cystic echinococcois after a long-term control program in Neuquén, Patagonia Argentina. Parasit Int. 2007;56: 149-155.

22. Zanini F, Gonzalo R, Perez H, Aparici I, Soto X, Guerrero J. Epidemiological surveillance of ovine hidatidosis in Tierra del Fuego, Patagonia Argentina, 19971999. Vet Parasitol. 2006;138:377-81.

23. Zanini F, Suarez C, Perez H, Elissondo MC. Epidemiological surveillance of cystic echinococcosis in rural population of Tierra del Fuego, Argentina, 1997-2006. Parasitol Int. 2009;58:69-71.

24. Larrieu E, Costa MT, Cantoni G, Labanchi JL, Bigatti R, Perez A, et al. Control program of hydatid disease in the Province of Río Negro, Argentina, 1980-1997. Bol Chilen Parasitol. 2000;55:49-53.

25. Perez A, Costa MT, Cantoni G, Mancini S, Mercapide C, Herrero E, et al. Vigilancia epidemiológica de la equinococcosis quística en perros, establecimientos ganaderos y poblaciones humanas en la Provincia de Río Negro. Medicina (Bs As). 2006;66:193-200.

26. Cabrera $P A$, Irabedra $P$, Orlando $D$, Rista L, Haran G, Viñals G, et al. National prevalence of larval echinococcosis in sheep in slaughtering plants: Ovis aries as an indicator in control programs in Uruguay. Acta Tropica. 2003;85:281-5.

27. Farias LN, Malgor R, Cassaravilla $C$ Braganca C, De La Rue M. Echinococcosis in southern Brazil: efforts toward implementation of a control program in Santana do Livramento, Rio Grande do Sul. Rev Inst Med Trop S Paulo. 2004:46:153-6.

28. Náquira C. Hydatidosis situation in Peru. In: Proceedings of the Scientific Working Group on the advances in the prevention, control and treatment of hydatidosis. Washington, DC: PAHO; 2003. Pp. 217-229. [Document PAHO/ $\mathrm{HCP} / 95 / 01]$.

29. Gavidia CM, Gonzales AE, Zhang W McManus DP, Lopera L, Ninaquispe B, et al. Diagnosis of cystic echinococcosis, central Peruvian Highlands. Emerg Infect Dis. 2008;14:260-6.

30. Vidal SM, Bonilla C, Jeria E. Gonzales C. The hydatidosis control program: the Chilean model. In: Proceedings of the Scientific Working Group on the advances in the prevention, control, and treatment of hydatidosis. Washington, DC: PAHO; 1994. Pp. 171-216. [Document $\mathrm{PAHO} / \mathrm{HCP} / 95 / 01]$

31. Alvarez JH. Estimación de la prevalencia de equinococosis canina en la XII Región, Chile. Parasitol Latinoam. 2002;60: 74-7.

32. Cabrera PA, Lloyd S, Haran G, Pineyro L, Parietti S, Gemmel MA, et al. Control of Echinococcus granulosus in Uruguay: evaluation of different treatment intervals for dogs. Vet Parasitol. 2002;103:333-40.

Manuscript received on 3 November 2010. Revised version accepted for publication on 12 July 2011. 